\title{
Feelings and Senses Given to the Music Present at the Hospital during Hemodynamic Procedures: Cardiac Catheterization and Coronary Angioplasty
}

\author{
Suzana de Albuquerque Paiva ${ }^{1}$, Jacqueline de Oliveira Moreira ${ }^{2}$, Francisco Rezende Silveira ${ }^{3}$
}

${ }^{1}$ Department of Post Graduation, University PUC Minas, Belo Horizonte, Brazil

${ }^{2}$ Productivity PQ 2 CNPq, Belo Horizonte, Brazil

${ }^{3}$ Department of Cardiology and Angiosemper, SEMPER Hospital, Belo Horizonte, Brazil

Email: *paivasuzana@gmail.com

How to cite this paper: de Albuquerque Paiva, S., de Oliveira Moreira, J. and Silveira, F.R. (2017) Feelings and Senses Given to the Music Present at the Hospital during Hemodynamic Procedures: Cardiac Catheterization and Coronary Angioplasty. Open Journal of Medical Psychology, 6, 31-51. http://dx.doi.org/10.4236/ojmp.2017.61003

Received: October 24, 2016

Accepted: December 16, 2016

Published: December 19, 2016

Copyright $\odot 2017$ by authors and Scientific Research Publishing Inc. This work is licensed under the Creative Commons Attribution International License (CC BY 4.0).

http://creativecommons.org/licenses/by/4.0/

(c) (i) Open Access

\begin{abstract}
Several studies indicate that music has soothing effects and is beneficial in reducing stress and anxiety in coronary patients. It is known that reactions to music are considered to be subjective, however, results of previous studies suggest that variables such as changes in heart rate, in cerebral blood flow and heart rate variability increase with a faster musical tempo, regardless of individual preferences. The effects of stress on the cardiovascular system have also been proven. However, the meanings assigned to music when used during hemodynamic procedures are unknown, as are the meanings of the experience of these procedures. The aim of this research is to understand the senses and feelings of music for patients undergoing hemodynamic procedures, identify and interpret the related fantasies and emotions and study the possibility of deploying in hospitals the "Musical Method for Hemodynamic Procedures", being developed by the author. This research is based on a Clinical-Qualitative Methodology. The sampling method is the theoretical saturation. The semi structured interview was used in order to obtain data that were submitted to content analysis. The subjects are patients undergoing hemodynamic procedures in the Hospital SEMPER (Permanent Medical Service), Belo Horizonte, Brazil. We conclude that within the experience of listening to music while undergoing catheterization, $100 \%$ of the patients interviewed claimed they had overcome the experience of stress and felt calm, tranquility, peace and happiness. Some patients described the music as a companion, as something that diverts their attention from fear, transporting them to an imaginary place, to another dimension. The episodic memory, the capacity to recognize a musical excerpt for which the spatiotemporal context surrounding its former encounter could be recalled, was also important, with surprising results, in the case of patients who underwent catheterization in the presence of music and, later, angioplasty without the presence of music.
\end{abstract}




\section{Keywords}

Clinical-Qualitative Research, Hospital, Hemodynamic, Health, Music

\section{Introduction}

Faced with the suffering of patients due to hospitalization, illness, physical and psychic pain and the necessary but often invasive procedures, we seek to relieve their pain and discomfort by offering them a more humanized treatment, based on our belief in the therapeutic effects of music.

We are not referring to music therapy stricto senso but rather of a new posture in relation to the use of music in the area of health: the so-called "Music Medicine" [1], a therapeutic approach for the use of music in a medical context.

Music therapy developed its practices and research with a qualitative methodology more related to humanistic traditions than to Medical Science. "Music Medicine" was developed as an isolated discipline, seeking to incorporate the legitimate therapeutic use of music within the medical context [1].

There is a lack of research on the theme of how music, what kind of music to use and administer so as to bring about a fruitful effect in specific clinical situations [1]. This deficiency stimulates the investment in research projects as well as in a specific musical method for hemodynamic procedures.

Knowing about the senses and feelings attributed to music during hemodynamic procedures and to the procedures themselves seems to be important as a way of increasing knowledge about the experience and the psychic and emotional aspects of cardiac patients since no publications on the subject were found in the researched literature (PubMed, indexed for MEDLINE, LILACS).

The search considered key words on these subjects, both in Portuguese and in English: qualitative research, hemodynamic procedures, senses and feelings of music in cardiac catheterization, coronary angioplasty, and health. Many articles were found that referred to stress, in aspects relating to physiological and psychological functioning, in the reactions and links of cardiopathies to music therapy [2]; to depression, specifically in women [3] [4] [5]; to cancer [6] [7] [8]; to children with burns, to pain and anxiety, in the post-operatory phase, to autism and other neurological conditions [9] [10] [11] [12]; to adolescents: about anxiety, use of alcohol, refugees [13] [14] [15]; about terminal patients: cancer and religion, well-being, relaxation [16] [17]; to qualitative research, on the human body, in the expressions of dementia, identity seeking, chronic respiratory diseases; to the perception of music by the caregivers of patients in an advanced stage of cancer, to "Music Medicine" [18] [19] [20] [21], among several others, but no article referred to the use of music during hemodynamic procedures or to the senses and feelings attributed by cardiac patients to music and to the procedures.

The therapeutic use of music in specific clinical situations, in a hospital context, would be a redemption, closely linked to the Greek tradition that in mythology, presented Apollo as the god of medicine and music. 


\subsection{The Heart}

Human creativity, intelligence and mastery are present in medicine and especially in cardiology, which treats a vital organ: the heart.

Here, we shall be talking about the heart with a psychological focus and in a symbolic, metaphoric way, without addressing the anatomical or clinical question of the heart.

The heart is the centre, the master of life and death; it determines us, threatens us and also encourages us. It makes us pulsate for love and for life, pulsate through fear and for death, that is, finiteness. The heart is also the "master of time", the time and the limit that it dictates. It is inscribed in and fills the anatomical and physiological dimensions, as well as the emotional and symbolic ones. It fills the lifespan and stops at the moment of death [22].

The heart is considered a central organ. The psychic associations made by hospitalized patients show the significance and the senses given to this organ. Themes such as love, death, fear of death, a life ill-spent, the neglect of health and other personal, profound reflections bear witness to how much the heart is associated with life and death, mainly at times when the individual and his health are fragile [22].

The thoughts of patients with suspected or diagnosed cardiopathies are mostly frightening. As an example, the words of a patient, just prior to undergoing cardiac catheterization: "If you are going to mess with (my) heart, well... that means I may die! It can stop! It's the heart, right? Haha (laughs)" [22].

"The heart commands the spectacle of life". This is the idea that prevails among cardiologists from various countries [23]. So, the heart is the conductor of this spectacle that is life, of which death is an integral part, as if it were a backdrop, or even the symphony that permeates the show.

In this show of life, Eros and Thanatos appear as the main actors. Eros is love [24] and Thanatos, death [24]. While love is elevated, death is denied. According to Freud [25] [26], it is impossible to imagine one's own death and every time we try to do so, we perceive we are still present as spectators. The psychoanalytical school affirms that "deep down, nobody believes in his own death and each one of us is convinced of his own immortality [25] [26]. Jung states that "it is obvious, evidently, that we are all going to die one day, and this is the sad end of everything, however there is something in us, it would seem, that does not believe this" [27] [28].

\subsection{The Cardiac Patient}

Most of the studies about stress and the effects of music when used with cardiac patients are quantitative. Professor Esler, of the Baker Heart Institute in Australia, wrote an article entitled "Mental stress is a cause of cardiovascular diseases: from skepticism to certainty", affirming that, in clinical practice of medicine, the integration of the idea that mental illness and stress contribute to the development of cardio-vascular is no longer subject to doubt, and that the evidence for this link is becoming apparent. This author says that the importance of acute mental stress as a trigger of cardiovascular diseases (acute myocardial infarction, sudden death) and depressive disorders, as being cause of cardiac diseases, is already a firmly established fact [29].

The psychiatrist Joel Dimsdale published in the Journal of the American College of 
Cardiology a long list of the effects of stress on the cardiovascular system, such as the effects of acute stressors, disasters such as earthquakes as well as those which are chronic, long-term such as stress at work, marital unhappiness and the weight placed on caregivers, all interfering in cardiac functioning [30].

It is known that music has a calming effect and may even be effective to reduce stress when used with cardiac patients [31].

The effects of relaxation and music therapy were assessed with patients who suffered infarction at an intensive therapy centre in Washington. Stress was measured by cardiac rate, peripheral temperature, cardiac complications and the qualitative data obtained while assessing the patient. The majority found that the therapy was valid in helping to reduce stress. They concluded that both the relaxation therapy and music therapy were effective in reducing stress in those patients. Cardiac complications were less in patients treated with relaxation and music than those in the control group [31].

Dynamic interactions between musical rhythms and the cardiovascular and cerebral systems were tested at the University of Pavia, in Italy. Periods of music and of silence were studied, measuring the heartbeat, breathing, blood pressure, the speed of the flow from the medial cerebral artery and vasomotion (modification in the tension of the blood vessels) of the skin; with the results showing that the musical emphasis and the rhythmic phrases are consistently followed by the physiological variables [32].

Reactions to music are considered subjective; however, previous studies suggest that cardio respiratory variables increase with a faster musical tempo, regardless of individual preferences [33]. Music does not only improve the quality of life but also brings about changes in heart beat and in the variability of the heart. Research carried out in the Department of Cardiology and Angiology at the University of Bochum, in Germany, showed that the cerebral flow was significantly lower when listening to Verdi's $V a$ pensiero, from the opera Nabucco when compared to Libiam nei lieti calici, from Verdi's La Traviata or Bach's Cantata no. 16: Gott soll allein mein Herze haben [33].

According to the authors, the music of many composers can effectively improve the quality of life, promoting and improving health and probably prolonging life, especially the music of Bach, Mozart or the Italian composers. The greatest benefit for health is visible with classical music and music for meditation, while heavy metal or techno are not just ineffective but also dangerous, leading to life-threatening stress and/or arrhythmia [33].

Psychology has brought effective contributions when working with the psyche, its influences and inter-relations with the emotional, corporal and experiences of people in hospital, in the light of Analytic Psychology [22].

A study headed by a researcher from the Universities of Harvard (USA) and of Athens (Greece), in which 23.681 healthy adults were followed for six years, showed that the habit of sleeping for an hour after lunch reduces the risks of fatal cardiovascular problems. Those who did a session of sleep therapy at least three times a week had a $37 \%$ less risk of dying from cardiac diseases than those who did not have this habit. The greatest benefit was seen in working men, probably due to the reduction in stress, a risk factor for cardiac health [34].

Relaxation is also necessary for health because it allows a pause in the stressful 
rhythm of daily life. "The most important and simplest tool we have to reduce the impact of stress is through relaxation exercises" [35].

Pires do Rio [36] also attributes innumerous benefits of relaxation for health, such as the capacity to memorize and active concentration; developing emotional balance; the recuperation of energy expended in physical and emotional efforts, the increase in the right choices at work, the reduction in the sensation of tiredness, the increase in the feeling of well-being, the reduction of psychosomatic manifestations, the regulation of the autonomous nervous system, with a decrease in the activity of the sympathetic nervous system (responsible for stress) and an increase in the parasympathetic nervous system, the improvement in inter-personal relations due to a greater tranquility and consequently emotional stability as well as helping reduce the incidence of angina and infarction [36].

According to Matthew M. Burg [37], a lot has been learned in the past thirty years of scientific investigation, but the exact role of stress and its influence on behavior and on heart disease require a deeper study. Perhaps, these risk factors are the most difficult to study but only through research will we find the indications for the prevention of stress and the most effective treatment [37] [38].

\subsection{Cardiac Catheterization}

Cardiac catheterization is a procedure carried out in order to diagnose and/or treat cardiac diseases. It assesses the functioning of the heart, the anatomy of the coronary arteries, the presence of atherosclerotic plaque (stenosis), alterations in the functioning of the cardiac valves, the presence of congenital pathologies and the pressures and oxymetries that allow various hemodynamic parameters to be calculated [39]. One of the most prevalent is coronary heart disease (CHD) [39].

\subsection{Coronary Angioplasty with Stent Implantation}

Coronary angioplasty with stent implantation is a technique carried out with the aim of unblocking one or more coronary arteries. A balloon is used (a catheter with a minute balloon at one end) which reaches the point of stenosis in the coronary artery and through inflation, unblocks the vessel with the implantation of a stent, making it easier or normalizing the flow of blood there). The coronary arteries are the vessels responsible for the supply of blood, oxygen and nutrients to the cardiac muscle [39]. When the arteries are obstructed by atherosclerotic plaques, it is difficult for the blood to flow, and may cause chest pain (angina pectoris) and/or acute myocardial infarction [39].

\subsection{Music}

Music reflects life. And life is contained in the rhythm of the heartbeat. This very rhythm can reveal dimensions of both the heart's and psychic health. Music is considered the most ancient of the sophisticated arts of communication, according to Galway [40]. It was developed from the main rhythms and vibrations of our planet: sounds of the wind and of water, of air and of fire. While living alone, at the mercy of nature, man sang to overcome fear, but also because he was fascinated by the sounds that surrounded him. The eminent musical culture of India, in antiquity, was never written 
down like that of Sumer, of Egypt or of China. No Asian musician would even dream of writing down his compositions, because its essence was improvisation. The greatest objective was inner contemplation, as Galway observed. For the ancient Greeks, music had therapeutic aims, purifying the mind and conciliating the soul through dance and song [40].

Music exerted a profound influence on involuntary physiology, capable of affecting the pulse and blood pressure, relaxing muscles, altering the breathing and affecting the emotions to the point of making you cry or even laugh [40]. It interferes in the system that regulates the emotions, thus constituting an ally to help hospitalized patients improve [22].

We believe that music can alleviate the psychic pain and consequently, physical pain too, of the patients at the time of carrying out hemodynamic procedures, when they reflect about life and their own death.

\section{Methodology, Subjects and Methodological Procedures}

Several studies related to stress due to cardiac risk factor, are basically of a quantitative nature, whereas the nature of the acoustic stimulus is qualitative. This research is based on a Clinical Qualitative Methodology, which deals with the investigation of symbolic meanings from reports of adults about phenomena that involves the health-disease process [41]. The subjects of the research are patients undergoing hemodynamic procedures, cardiac catheterization or coronary angioplasty. The semi structured interview was used in order to obtain the data.

The sampling method used was the Theoretic Saturation, that is, the group was closed when the speeches of the patients showed important senses and meanings for the comprehension of the theme and, apparently, were not adding new information to the research. For the analysis and interpretation of the data, we used the Qualitative Content Analysis of the Interviews [41] [42].

The qualitative analysis of the content must be carried out from suspended reading (suspended attention) of the transcribed interviews, from a pre-analysis following the stages of categorization of the elements and a thorough discussion of all this [41]. We seek an interpretation of the data from the interview, clinically underpinned in the theory of Analytical Psychology [43].

The research subjects are patients of both sexes who were admitted to hospital with the recommendation that they should be submitted to cardiac catheterization or coronary angioplasty, who agreed to take part after receiving details of the study, ethics and professional confidentiality. There was no prior selection based on age, sex, schooling or social class. The subjects for the research were chosen at random among the patients who were admitted to that hospital to undergo hemodynamic procedures.

The research was carried out in hemodynamic service at the Hospital SEMPER, Belo Horizonte, from November 2014 to July 2015. It was authorized by the head of the ICU (Intensive Care Unit) and the Coronary/Hemodynamic ICU, Dr. Francisco Rezende Silveira, as well as the doctors who carried out the procedures: Dr. José Walter Mendes Nogueira and Dr. Carlos Eduardo Diniz Couto. This year (2016) we are following up the reports of patients who are benefitting from the musical program. The main aim is 
to update the music program in the hemodynamic sector, based on the style of music most chosen and by what the patients say about their experience with music.

\section{The Semi-Directed Interview}

The semi-directed interview was used as the methodological resource for data collection. The senses and feelings about the phenomena are the very essence for qualitative researchers. Our aim is to capture them by listening and observing the research subjects, as well as by giving interpretations [41].

Two interviews were carried out before and after the procedure, respectively. First there is an initial interview, before the procedure, lasting on average between thirty and sixty minutes, to present and obtain data and explanations about the research, explaining its importance, their possible participation as well as ethical questions depending on the patient's evolution. The necessity of using a recorder was made clear and the subjects were asked to read and sign the Informed Consent Form. Thanks were given for their collaboration.

Personal data was sought with regards habits related to the use of music and the questionnaire on musical preferences was applied so as to determine the choice of music style that would accompany the patient during the procedure.

Following this, a semi-directed interview was carried out post-procedure to determine the senses and meanings of the procedure and the music, lasting on average fifteen to thirty minutes. This procedure took place when the patient showed that he was in physical and psychological conditions to answer the questions.

The interviews were given by the researcher responsible for the study and the patients were free to interrupt the interview if they so wished (this did not happen). Psychological counselling was offered, if it became necessary during the interventions or hospital stay.

\section{Discussion}

The majority of hospitalized patients are fighting for their lives. The patient does not want to die, he fears death. He wants to be cured and to return to normal life. He plans the necessary changes to improve his life in various aspects, at the present time and in the future [22]. Hospitalized patients yearn to go back to work, to love, to live among others, to carry out his chores and desires, longing to be discharged from hospital [22]. Patients who have to undergo hemodynamic procedures are worried about the hemodynamic procedures that "touch" the heart, without anesthesia as they have to follow the doctor's recommendations and instructions [22]. Many wish for anesthesia, a sedative, not wanting to know what is going on, wishing to sleep and wake up when it is all successfully over. The exam frequently makes the patient anxious, worried and ultimately fearful of dying and this emotion is expressed and elaborated on during the counselling given in the hospital [22].

Music appears as an instrument that can assuage this tension, creating a rich and harmonious physical and psychological atmosphere, full of mental images, symbols of the unconscious, of dreams and possibilities.

In our study, we verify the importance of the episodic memory in the case of patients 
who underwent catheterization with music and angioplasty without the presence of music.

Episodic memory for musical information is defined by Platel and colleagues [44] as "the capacity to recognize a musical excerpt (whether familiar or not) for which the spatiotemporal context surrounding its former encounter (i.e., when, where, and how) can be recalled". To go deeper into the question of the episodic memory, Platel [45], on the basis of a high-resolution positron emission tomography study, delineated different brain networks involved in processing semantic and episodic memory. For episodic musical memory they found increases in cerebral blood flow bilaterally in the middle and superior frontal gyrus region (with a left-sided preponderance) and the precuneus, whereas for semantic musical memory there was a blood flow increase bilaterally in the medial and the orbitofrontal cortex, the left angular gyrus, and the left anterior part of the middle temporal cortex. From these findings one can conclude that these two different musical memory systems have a different neural representation. It is interesting to note that these brain areas partly overlap with verbal semantic and episodic memory systems.

Numerous functional imaging studies have shown that retrieval from semantic and episodic memory is sub-served by distinct neural networks [44] [45].

It is also interesting to note that listening to music is not only accompanied by blood flow increases in brain areas known to be involved in generating and controlling emotions [46] [47], but it is also accompanied by a general increase and change of brain activation within a distributed network comprising many brain areas and the peripheral nervous system [44] [48] [49]. Thus, listening to music (even when we listen passively) activates many psychological functions (emotion, memory, attention, imagery and so on) located in a distributed, overlapping brain network [50].

Another important study, by Eschrich and colleagues [51], is consistent with the rest of the literature on emotion as a memory enhancer. Thus, emotion enhances not only memories for verbal or pictorial material, as summarized by Buchanan [50], but also for musical pieces.

According to Jäncke [52], several papers [53]-[59] have looked at the role of music in memory formation and recall of autobiographical and episodic information, and a recent paper in BMC Neuroscience in particular gives new insights into the role of emotion in musical memory [51]. Jäncke also points out that collectively, these papers emphasize the enhancing role of music and emotion on memories in various contexts [52].

Various studies and research on themes referring to memory and to music can be found in the literature [60]-[65].

We observe the importance of episodic memory in what concerns the preservation of the lived experience.

Our hypothesis questions whether the musical intervention could offer a more pleasant experience of hospitalization and of the procedures, in relation to the fantasies and fears experienced prior to the procedure, and the results found were positive.

\section{Results}

The following categories and subcategories of analysis were identified:

1) Pre Procedure Moment 
A: Feelings and imaginary fantasies about the exam: disquiet, denial, fear apprehension, worries, fright, peace. Music carries you away.

B: Patients who prefer to do it without music.

2) View of Music during the Procedure

A: Improves physical and mental health, reduces stress, brings calm, tranquility and peace.

B: Music brings happiness, confidence, strength and faith.

C: Music seen as a companion.

3) Feelings Post Procedure

A: Music relaxes, calms you down.

B: It brings peace.

C: It takes you out of that situation and worries.

4) Experiences of Episodic Memory

A: Interview 13.

B: Interview 14.

We now present some of the patients' utterances, taken from the interviews:

1. Pre-Procedure Moment

A-Feelings and imaginary fantasies about the procedure:

Disquiet

-What did you feel, think when you found out you were going to do the procedure?

"Disquiet! Ah!!! P m very uneasy about anesthesia. It's normal, P ve already had an operation. Collapsed brain. It all went well, today it doesn' t even seem possible!! I saw it on the screen and I really had a fright!! With music, it's going to be very smooth!" Interview 1 (male).

Denial

"Nothing! Nothing! It's the third time I do it! Ah! The first time, ah...I was a little apprehensive." (about the procedure).

-He chose classical music. He's not really into music.... He likes football.

"Music... hum, more or less, not much! Football, yes!" (and he smiles!).

-But he thinks it is going to be "good, very good!"

-Why do you think that it is going to be good?

“Because it will relax (me)!” Interview 2 (male).

Fear

-As soon as I began the explanations about the research and the use of music, she says:

“It's good!!" smiling! Enthusiastic.

-Feelings: "Fear, fear of dying. It is going to touch my heart!!! I already underwent three procedures - in one, the bed collapsed! The first wasn't the worst because I didn't know anything and it took me by surprise. It all happened so fast. I ve been in hospital twice, I did two catheterizations and four angioplasties. One 'cathe'(terization) in 2005 and another in 2012. This is the third. Now it is more difficult because I know how it is! The pain... When the bed collapsed, it cut my vein and I had a hemorrhage, I almost died. I was in the ICU."

"The waiting creates anxiety. It's the most difficult (part)! The Spiritualist Doctrine 
helps me a lot. And thinking about nature helps me, calms me down...little fish, rivers, undergrowth!" (she smiles). Interview 3 (female).

-How are you feeling?

"Fear! A lot of fear! I was scared. Yesterday I had to do some work to distract myself, to change my luck... to calm me down! But I already asked God! It's because there is a family history. In my prayers, I asked for help for the doctors, all of them, so that it turns out all right. And it will. I felt a lot, really a lot of fear! But I am eighty years old, yes, but I still have a lot of things to do, that I want to do... so God is not going to take me... I still want to do a lot of things... ah, some things. I have done so many things in my life but I still have more to do...!” (smiling a lot). Interview 11 (female).

\section{Apprehension, tension, worry, terror}

"Ah! I think it's good! Yes" (nodding her head in agreement). His wife relates that he likes music and listens to music all day long! "On the transistor radio!" (smiling).

-How are you feeling?

“Ah! Apprehensive! Very worried!" (laughing).

-Do you think music will help?

"Ah! It takes away the tension. Music helps a lot. It takes away the tension from it, from the exam. Ah, I didn't want to know about it! My mother did it and there was a problem, so I really don't want to think about it. Because it is going to tamper with the vein and the heart, right? We get apprehensive! But it is better not to think about it. And music is really good, it takes away bad thoughts, like, it's going to hurt, there's going to be a problem... Ah! a problem... something bad may happen..." Interview 12 (male).

"Ah! music? Ah! It's wonderfu! Yes, I want (music)! Ah! Classica!! Beautifu! Bach? Ah! Marvelous!”

-Patient relates that she loves music and that she is a singer!

"You know Suzi, I was thinking that catheterization was something really horrible!"

-Horrible in what way?

"Ah! Like, full of apparatus, that I was going to have to stay with my leg like this, straight, upright and it was going to hurt. Ah! I thought they were going to open my heart and it's the heart, you know...? Then I wouldn't be coming back again, I wasn't going to pull through! The doctor was going to talk to my sister. Ah! She didn't make it! But God is the only one who knows, right?" Interview 6 (female).

"Yes, I would love that! But something very gentle!"

-She chose Sounds of Nature.

"I think a lot about others. I always want to help. I worry a lot! About everything, but mainly about others. And I forget about myself?" "Ah! It's got to be done, right? So I came (here). I am very worried. About everything!"

-What about? What would be "everything"?

"I went for a routine check and the doctor asked for a test. I found that strange. I got frightened. After the doctor saw it, he said I had to do another, the catheterization and the sooner, the better! That's what he said: Look, I don't want to frighten you but you'd better do it soon! I got frightened. But it has to be done, right? I obey." "I pray for everybody and forget myself.' Interview 7 (female).

"But before I was terrified. Very scared, it runs in the family... I thought I wouldn't 
survive, that they would have to open my heart. That it would have to be surgery!" Interview 11 (female).

-The patient seemed to be calm. -How are you feeling?

"Calm only on the outside! Inside ......really agitated! Because I am a perfectionist, but with others, not with myself! (laughter).

-Are you more bothered with your own imperfection or other people's? He rapidly answers:

“Other people's! (smiling). How much am I going to have to pay for this?" (the music).

-Nothing, I answered, "it's a service of the SEMPER hospital.

"It's the fifth time! (he shows me with his hand). Will I get to go home?" Interview 8 (male).

“Ah! Yes! I think it will be good! I couldn't sleep last night...from worry!"

-What did you think or worry about?

"Ah! The surgery... I got upset, thinking that there might be a problem...! A complication! People tell me it hurts, that it reaches the heart and if it reaches the heart, it's worrying, right? 70 years! But the doctor explained everything, that they were going to do a test to see if it was blocked and then another to put in the stent to unblock, if it is blocked!" Interview 9 (female).

Explanations have a calming effect

"Yes, it helps! I want Classical, it's peaceful. The test is also peacefu! When the doctor explained everything carefully, it makes you feel safe. We know what it's for, that it's for prevention! I am calm!" Interview 5 (female).

\section{Peace}

“Ah! Yes, I want music! Can I listen to a little bit? I choose classica! Ah what peace! That's wonderful! I $m$ not very worried at all, the doctor requested this (procedure) because I have to undergo hernia surgery, which hurts a lot: So that's good, I thought, it's necessary and it's going to be fine, right? To see if there is any blocked vein in the heart. So then I can undergo the surgery and everything will be alright, thank God!" "But then people said it was bad, it would hurt, even the girl who is a nurse told me I could even die!! So then I felt like this, worried! But God will help!"

-The 80 year old patient smiles when looking at me during the prep and the procedure and keeps repeating:

“The day starts at dawn! God be praised, what happiness!!” Interview 10 (female).

\section{Being carried away}

“Ah! Yes! I do want (music)! Marvelous! Music carries you away! Classical; I love music. Yes, I have a habit of listening. I used to sing in a choir." Interview 11 (female).

\section{B-Patients who prefer not to have music:}

-First question: I am carrying out research on the hemodynamic procedures. Would you like to take part?

-Second question: would you like to listen to music during the procedure?

-He joked: “Can it be rock? (laughter). Do you have 'pagode' (NT: Popular Brazilian Music)?? (laughter). Do we have to pay?"

"No thank you. I $m$ not in the habit of listening to music, only if it is the hymn of my 
football team. Is that possible? (laughter). I prefer silence, my wife would really like it! Not me, no!"

-In the end, when the procedure was over, while he was waiting to return to his room and he heard the music that was being offered to another patient who was waiting, he said the following:

"Marvelous!! Music is the most important of the Arts. Very good! Your research is very important. Ah, I would have liked to have it. I think it would help a lot because there is no anesthesia for the patient, right? Good luck to you and your research!!" Interview A (male)

“Ah! I am really nervous!" “No, I prefer silence! I am very nervous". Interview B (female).

-The patient refused and said she preferred silence! However, when I went to talk to her, she was already in the hemodynamic room, prepped for the start of the procedure, the "Cate". She was pacing from one place to another and did not even want to lie down. I spoke to her first about the research; she refused. And she was very nervous.

The therapeutic effect of the use of words:

-I observed that when the subject "research" was used at the beginning of the first contact with the patients, the negative reaction was immediate: shaking their head and then saying: "No thank you!" It was as if the word "research" caused a negative impact, of uneasiness, rather frightening. Beginning the contact with the question: Would you like to have music to accompany you during the procedure? always provoked a reaction of curiosity, a smile, an opening for explanations and agreement to have a musical accompaniment.

2. View of music during the procedure

A-It improves physical and mental health, it reduces stress, provides calm, tranquility and peace:

$100 \%$ of those interviewed claimed that music helped them overcome the stressful experience:

“Because it relaxes!" Interview 2 (male).

"I liked it a lot! It was marvelous. Marvelous music. Catheterization isn't such a big dea! Now $1 \mathrm{~m}$ going to defend catheterization". Interview 6 (female).

"It was great! Because I saw nothing!"

-At the end, he said that music helped "a lot"! That it had a relaxing effect and helped pass the time.

"It was good, very good!" and he smiled! "Yes, it was great. I was like this (closes his eyes) very relaxed!" A Approved!" He smiled and closed his eyes. He said that music took him away from there. From worrying!

"It made it pass more quickly!" Interview 2 (male).

"Thank you! It helped me a lot!" "Ah! We are distracted by the music and don't stay watching nor thinking bad things! Yesterday I said: P m pushing a cart up a hill! (And he laughed a lot). "It was really very good. Much better with the music. I loved it!"

-The patient identified some birds, such as João Velho, which according to her, sings a lot. "It helped to calm (me). I was very nervous!" Interview 3 (female).

B-Music bringing happiness, confidence, strength and faith: 
-The wife says he is the mother of patience. She asks me, in the end, when he is already in the recovery room, sleeping:

"Did you see how happy he was when you spoke of music? He gave a huge smile!!!" (laughter).

"It was great! Because I saw nothing! It improves health. Excellent! It was a different experience and it left me so relaxed that I saw nothing of the procedure. It was like a deep sleep. It helped a lot. Because I was listening to the music I like. Thank you, team. Competent and great professionals." Interview 1 (male).

"I liked it a lot. It was marvelous. Marvelous music!!!"

"Catheterization is not such a big thing! Now I am going to defend catheterization." Interview 6 (female).

"It increases confidence, strength and faith!!" Interview 3 (female).

\section{C-Music as a companion:}

-Others described the music as a companion, as something that distracts their attention away from fear; music transports them.

"I didn't feel alone, music was my companion! It was great!"

"The music helped a lot! You can write that down there in your research, music helps a lot. It makes you feel good, music played low like that, gentle! I got nervous when the nurse couldn't find a vein. She tried one arm and nothing then the doctor (anesthetist) came and was successful. When the nurse said something was happening, there in the machine, I had a fright. Then I looked at the apparatus and she said everything was yellow and I saw everything was moving and I thought 'there you are, there's no way this is going to work. It's now! But then I heard the music and chose to pay attention to the music and it soothed me! I didn't feel alone. It accompanies you and leaves you... far from there and from the worries. You are an angel" Interview 7 (female).

-The patient's daughter also said I was an angel. They thanked me a lot and wished me well, "God be with you!"

The angel symbolizes the invisible, the forces that rise and fall between the origin and the manifestation. In alchemy, the angel symbolizes sublimation, the ascension of a volatile (spiritual) principle. Angels have appeared in the artistic iconography since the origins of culture, in the 4th century BC and are confused with the winged divinities. Gothic art expressed very many prodigious images: the protective and sublime aspect of the angel, whereas the Romanesque laid greater emphasis on their super-terrestrial character [66].

Symbols and archetypes are important concepts in Analytical Psychology. According to Jung [67], "the concept of archetype indicates the existence of certain forms in the psyche that are always present everywhere". The author also states that "the mythological research calls them the "reasons" or "themes"; in the psychology of the primitive populations they correspond to Levy-Bruhl's concept of représentations collectives and in the religious sphere they were defined as "categories of the imagination" by Hubert and Mauss. Long before this, Adolf Bastian appropriately designated them as "elementary" or "primordial thoughts", from the Greek where arché means "archaic, primordial" and typos means "types, marks". According to Plato, the idea preexists and is superordinate to the phenomena in general. Therefore, "The Archetype is nothing more than 
an expression that already existed in Ancient times and a synonym of "idea" in the Platonic sense" [67].

\section{Post-Procedure Feelings}

\section{A-Music relaxes, calms you down:}

-When he awoke, the patient said that they hadn't even started to prep him for the procedure. His wife replied that he had already undergone the procedure and he didn't believe her.

"He didn't see anything. Because when he woke up, he said they hadn't even prepped him for the procedure. That was when I answered him that he had already done it and he didn't believe me. He only got confirmation when I told him to put his hand on his groin and see that he was no longer in the procedure room and not in the recovery room." (wife)

"It was great because I didn't see anything!" "It improves health." "Excellent! It was a different experience and it left me so relaxed that I saw nothing of the exam. It was like a deep sleep." "It helped a lot. Because I heard the music I like."

"Thank you, team. Competent and great professionals" (Written account given by patient's wife). Interview 1 (male).

-At the end, the patient said that the music helped "a lot"! That it relaxed and helped pass the time.

“It was good, very good!" and he smiled! "Yes, it was great. Very good! I was like this... (he closed his eyes) very relaxed!" "Approved! Yes, and classical music is the best! Popular Brazilian music, no! (he turns up his nose), Sounds of Nature...good! Oriental no!" He smiles and closes his eyes!

-He said the music took him away from there! From worry!

"It made it go more quickly!" Interview 2 (male).

"The Spiritualist Doctrine helps me a lot. And thinking about nature helps me, calms me down...little fish, rivers, countryside!! (she smiled). I ride a horse! I have a mare and my husband has a horse. We like to ride." "Thank you! It helped me a lot!"

"Ah! We get distracted by music and don't stay looking, or thinking about bad things!" Yesterday I said: "I am pushing the coffin uphill!" (and he laughed a lot). "It was really good! Much better with music! I loved it! It helped calm me down, I was very nervous!" Interview 3 (female).

-Patient sleeping, with difficulty to speak. He made a gesture showing that it was very good to have the music. "It calmed me down!" Interview 4 (female).

"I liked it a lot. It was marvelous. Mavelous music!!! Catheterization isn't all they say it is. Now P m going to defend catheterization."

The patient is visually impaired and started to call me Suzy, Suzinha. She suggested Chopin! I told her that her suggestion would be followed. Interview 6 (female).

\section{B-It takes us away from the situation and worries:}

“ $A$ h! It was great. The music helped a lot. We stop thinking like that, about the problem, in our imagination and pay attention to the music! Really good! I really, really liked it. Thank you so much!"

-Gazing at me, still listening to the music, she says:

“Very good! It's very good. With music!" (and smiles). Interview 9 (female). 


\section{C-It brings peace:}

"I felt Peace, from the first moment I saw you. You were talking and I felt PEACE!!" (smiling). "Thank you very much! Music brought Peace, Very good! It helps to relax! You can implant it in the hospital, can't you? For everybody! It will be really good! I felt great Peace here, with you and with everybody, the anesthetist, he's lovely, the doctor is the one that talked to me! It's true... everybody, the hospital, very good!" Interview 10 (female).

"Marvelous!" "You are an ange!! You were my angel who stayed with me at my bedside! You carried me away! I remembered the church bells! But before I was terrified! So much fear, it runs in the family... I thought I wouldn't survive, that they would have to open my heart. Resort to surgery!" Interview 11 (female).

"It was worthwhile! It was very good, P Il sign up again! (laughing). My son yesterday asked the family on Whatsapp, right? Prayers!!!... for me!... that's how people think, right?... that something could happen, right?" (laughs) Interview 12 (male).

\section{Experiences of the Episodic Memory}

Patients, who had undergone catheterization with music, returned to the hospital to undergo angioplasty and asked for music but since it was not the day of the research, it was not possible to do it with music. When they learnt this, I thought they would report that it had been very bad without music, very different from the experience of catheterization with music. However, they immediately remembered the first experience and with the memory of the music, the sensations of well-being, relaxation, happiness took over and they managed to relax. This was thanks to the episodic memory.

To exemplify the effects of episodic memory, evidenced in these experiences, we shall see below parts of the interviews of two patients who reported their experiences during angioplasty without music, when catheterization had been carried out with the presence of music.

Having been accompanied by music during catheterization left a feeling of tranquility, which overflowed into the second procedure, the angioplasty. The patients related that they really missed the music during the second procedure but it was as if the impression it had left and the well-being they felt had been preserved and somehow transported to the second procedure. (Interviews 13 and 14).

\section{Angioplasty}

\section{Interview 13 (female)}

"I was terrified during the catheterization! Worried, but with the music in the background and the conversation with you, I became calm. The doctor has a lot to do. Our conversation was good. When I returned to do the angioplasty, I did imagine how it would be without music, I asked after you. The second time even the doctor said how calm I was."

"But the first time, when the doctor told me I had to do it, I had a fright! But talking to you and with the music, it was fine, I was calm... it's one of those things. I imagined that something could happen. The first time, you imagine that something could happen, something inside, that goes to the heart... it was one of those things that I imagined could happen! But then I really relaxed! And the second time it was calmer! But I was thinking about the music, that there would be music and you would be here! So I asked 
after you, I wanted to do it with music and with you, but they told me you weren't in the hospital "Ah! She's not here!" You weren't here that day. I became anxious because it had to be changed. I was going to do it on Monday and they changed it to Tuesday. I was upset. Ah, because I was already waiting and to have to wait more is bad! And I was preparing to do it straightaway. That was really bad but God knows how things work! How it changes, like when there are clowns for the children, they smile, they even become happy, contented!! People in hospital, ah, there are only downhearted people. They don't have their families, home cooking, things are happening out there and we are in here! In hospital. We value life, it brings happiness! And when I arrived for the angioplasty, I commented: Suzana isn't here today, right?"

"So the music helped a lot, the first time and that tranquility remained for the second time! So it was good!"

-The patient shows how the tranquilizing effect of the music lasted and allowed the second procedure to be felt and experienced with more serenity. She affirms that it will be very good if the hospital could offer music to accompany the patients during hemodynamic procedures.

The fact of having been accompanied by music during the catheterization left an impression of peacefulness that remained for the second procedure, the angioplasty, from the moment that it was known that it had to be done. The patient relates that she really missed the music, during the procedure but it is as if the impression it left and the well-being she felt during the catheterization had been preserved and transported to the second exam, thus evidencing the effects of episodic memory.

We see that the sensations experienced with the music during the first procedure were extended and accompanied the patient into the second:

"From the experience, from the first time, I felt relaxed and everything, listening to the birds!! And the second time, I didn't worry, it was very good! We feel worried. But I didn't feel a bit worried the second time! I remembered the music!! And you!"

\section{Interview 14 (female)}

"The music! I really missed the background, with music!

-Why?

"Because the music accompanies the patient. There's a lot of pain when they insert the tube! I was always apprehensive, afraid of the pain, it hurts a lot, it's fleeting, minutes, five minutes, but it's pain, pain... Afterwards I got very anxious. I arrived in the ICU at four in the afternoon; I had a good night, without any changes. It was difficult. Even more difficult to stay in that room there, I cried a lot. I don't know whether I was trapped or holding on to something and so as not to cause any alteration for the doctor, I cried a lot: See how I missed you-me, alone in pain, I cried a lot. I remembered the support you gave me in the 'Cate'!"

"I couldn't speak-it's an aggression not to have an anesthetic, isn't it? I asked the doctor. Just for one minute. I was trembling inside. The nurse asked "Why are you crying?" Ah! I missed the music!! The music shows another path and we can disconnect from those worries! I missed it. I really did. You, the music! Because you accompany me. It's so good! You can go on with your work. It's worth while."

"I cried. I think it was an outburst, something I had pent up. But I remembered the 
music and you and I calmed down. Music takes your mind in another direction, calmer, making us more confident. I have a lot of faith in God but at that moment it was very difficult."

"It was very good with the music. There are people who think music is going to get in the way, but it can also have a calming effect. I personally don't like music very much; I don't have the patience to keep listening. I like religious music. I used to sing with the children! It was good for me, so, for whoever likes music, it would be even more so. The music you put on for me brings calm, relaxes, increases confidence, strength and faith!!”

\section{Conclusions}

We can observe the importance of music for the hemodynamic patients insofar as psycho-emotional aspects are concerned. Music not only helped diminish stress but also brought about changes in mood. The sensation of fear, uneasiness and terror were substituted by feelings of strength, contentment, happiness and states of tranquility, faith and peace.

It was very important to evidence the satisfaction reported by the patients on having music as a companion, as a real comfort for the heart, alleviating the idea of being alone to face the possibility of death.

We verified the enormous value of the episodic memory in the capacity demonstrated by the patients when, as they remembered the experience with music during the first procedure, they were able to bring to the new procedure without music, the sensations of well-being they had experienced, as if they were accompanied by music in this second moment. Just by remembering the first experience, the second was experienced as if the music were present, with its effects, during the whole time, including the preand post-procedural moments.

As the results of this study revealed that the use of music was beneficial for the patients undergoing hemodynamic procedures, the board of directors of AngiosemperDepartment of Hemodynamic of the Hospital SEMPER, decided to implant the Musical Method for Hemodynamic Procedures, developed by the author, in a more specific and permanent form, as a part of the hospital's routine.

\section{Declaration of Conflicting Interests}

The authors declared no potential conflicts of interest with respect to the research, authorship, and/or publication of this article.

\section{Funding}

The authors received no financial support for the research and authorship. Financial support for the publication of this article was received from the Fundação de Amparo a Pesquisa de Minas Gerais, FAPEMIG.

\section{Approval}

Research is approved by the Ethics Research Committee in the Hospital SEMPER and approved by the Ethics Research Committee for CONEP (37043214.6.0000.5137). 


\section{References}

[1] Myskja, A. and Lindbaek, M. (2000) How Does Music Affect the Human Body? Tidsskr Nor Laegeforen, 120, 1182-1185.

[2] Thoma, M.V., Scholz, U. and Nater, U.M. (2011) Listening to Music and Physiological and Psychological Functioning: The Mediating Role of Emotion Regulation and Stress Reactivity. Psychology \& Health, 27, 227-241. https://doi.org/10.1080/08870446.2011.575225

[3] Lai, Y.M. (1999) Effects of Music Listening on Depressed Women in Taiwan. Issues in Mental Health Nursing, 20, 229-246. https://doi.org/10.1080/016128499248637

[4] Stacciarini, J.M. (2008) Focus Groups: Examining a Community-Based Group Intervention for Depressed Puerto Rican Women. Issues in Mental Health Nursing, 29, 679-700. https://doi.org/10.1080/01612840802128998

[5] Ying, L.C., Levy, V., Shan, C.O., Hung, T.W. and Wah, W.K. (2001) A Qualitative Study of the Perceptions of Hong Kong Chinese Women during Caesarean Section under Regional Anesthesia. Midwifery, 17, 115-122. https://doi.org/10.1054/midw.2000.0249

[6] Barry, P., O’Callaghan, C., Wheeler, G. and Grocke, D. (2010) Music Therapy CD Creation for Initial Pediatric Radiation Therapy: A Mixed Methods Analysis. Journal of Music Therapy, 47, 233-263. https://doi.org/10.1093/jmt/47.3.233

[7] Barrera, M.E., Rykov, M.H. and Doyle, S.L. (2002) The Effects of Interactive Music Therapy on Hospitalized Children with Cancer: A Pilot Study. Psycho-Oncology, 11, 379-388.

https://doi.org/10.1002/pon.589

[8] O'Callaghan, C.C., Homby, C.J., Pearson, E.J. and Ball, D.L. (2010) Oncology Staff Reflections about a 52-Year-Old Staff Christmas Choir: Constructivist Research. Journal of Palliative Medicine, 13, 1421-1425.

[9] Nguyen, T.N., Nilsson, S., Hellstrom, A.L. and Bengtson, A. (2010) Music Therapy to Reduce Pain and Anxiety in Children with Cancer Undergoing Lumbar Puncture: A Randomized Clinical Trial. Journal of Pediatric Oncology Nursing, 27, 146-155.

https://doi.org/10.1177/1043454209355983

[10] Nilsson, S., Kokinsk, E., Nilsson, U., Sidenvall, B. and Enskar, K. (2009) School-Aged Children's Experiences of Postoperative Music Medicine on Pain, Distress, and Anxiety. Pediatric Anesthesia, 19, 1184-1190. https://doi.org/10.1111/j.1460-9592.2009.03180.x

[11] Heaton, P. and Allen, R. (2009) "With Concord of Sweet Sounds...": New Perspectives on the Diversity of Musical Experience in Autism and Other Neurodevelopmental Conditions. Annals of the New York Academy of Sciences, 1169, 318-325. https://doi.org/10.1111/j.1749-6632.2009.04583.x

[12] Whitehead-Pleaux, A.M., Zebrowski, N., Baryza, M.J. and Sheridan, R.L. (2007) Exploring the Effects of Music Therapy on Pediatric Pain: Phase 1. Journal of Music Therapy, 44, $217-$ 241. https://doi.org/10.1093/jmt/44.3.217

[13] Primack, B.A., Nuzzo, E., Rice, K.R. and Sargent, J.D. (2011) Alcohol Brand Appearances in US Popular Music. Addiction, 107, 557-566.

[14] Walker, I.J. and Nordin-Bates, S.M. (2010) Performance Anxiety Experiences of Professional Ballet Dancers: The Importance of Control. Journal of Dance Medicine \& Science, 14, 133-145.

[15] Choi, C.M. (2010) A Pilot Analysis of the Psychological Themes Found during the Caring at Columbia-Music Therapy Program with Refugee Adolescents from North Korea. Journal of Music Therapy, 47, 380-407. https://doi.org/10.1093/jmt/47.4.380

[16] Okamoto, T., Ando, M., Morita, T., Hirai, K., Kawamura, R., Mitsunori, M., Sato, K. and Shima, Y. (2009) Religious Care Required for Japanese Terminally Ill Patients with Cancer from the Perspective of Bereaved Family Members. American Journal of Hospice and Pal- 
liative Care, 27, 50-54. https://doi.org/10.1177/1049909109346562

[17] Bums, S.J., Harbuz, M.S., Hucklebridge, F. and Bunt, L. (2001) A Pilot Study into the Therapeutic Effects of Music Therapy at a Cancer Help Center. Alternative Therapies in Health and Medicine, 7, 48-56.

[18] Lonsdale, A.J. and North, A.C. (2011) Why Do We Listen to Music? A Uses and Gratifications Analysis. British Journal of Psychology, 102, 108-134.

[19] Lord, V.M., Cave, P., Hume, V.J., Flude, E.J., Evans, A., Kelly, J.L., Polkey, M.I. and Hopkinson, N.S. (2010) Singing Teaching as a Therapy for Chronic Respiratory Disease-A Randomized Controlled Trial and Qualitative Evaluation. BMC Pulmonary Medicine, 10, 41.

[20] Gotell, E., Brown, S. and Ekman, S.L. (2009) The Influence of Caregiver Singing and Background Music on Vocally Expressed Emotions and Moods in Dementia Care: A Qualitative Analysis. International Journal of Nursing Studies, 46, 422-430. https://doi.org/10.1016/j.ijnurstu.2007.11.001

[21] Smeijsters, H. and van Den Hurrk, J. (1999) Music Therapy Helping to Work through Grief and Finding a Personal Identity. Journal of Music Therapy, 36, 222-252. https://doi.org/10.1093/jmt/36.3.222

[22] Paiva, S.A. (2010) Quando o mal estar social adoece o coração: O infarto à luz da hipermodernidade. Annablume, São Paulo.

[23] Faraj, M. (2005) As bases fisiológicas do aparelho cardiovascular. In: Filho, P.W.C., Barbosa, M.M. and Chula, E.D., Eds., Cardiologia: Sociedade Mineira de Cardiologia, Rio de Janeiro: Medsi; Guanabara Koogan.

[24] Brandão, J.S. (1986) Mitologia Grega. Vozes, Petrópolis.

[25] Freud, S. (1969) Edição Standard Brasileira das Obras Psicológicas Completas de Sigmund Freud: v.21: O futuro de uma ilusão; o mal-estar na civilização e outros trabalhos. Imago, Rio de Janeiro.

[26] Freud, S. (1969) Edição Standard Brasileira das Obras Psicológicas Completas de Sigmund Freud: v.21: O Mal Estar na Civilização. Imago, Rio de Janeiro.

[27] Jung, C.G. (1959) Face to Face, Interview. BBC, NTSC: son., Küsnacht.

[28] Hull, R.F.C. and McGuire, W. (1977) C.G. Jung: Entrevistas e Encontros. CULTRIX, São Paulo.

[29] Esler, M., Schwarz, R. and Alvarenga, M. (2008) Mental Stress Is a Cause of Cardiovascular Diseases: From Skepticism to Certainty. John Wiley \& Sons, Hoboken.

[30] Dimsdale, J.E. (2008) Psychological Stress and Cardiovascular Disease. Journal of the American College of Cardiology, 51, 1237-1246. https://doi.org/10.1016/j.jacc.2007.12.024

[31] Guzzetta, C.E. (1989) Effects of Relaxation and Music Therapy on Patients in a Coronary Care Unit with Presumptive Acute Myocardial Infarction. Heart \& Lung, 18, 609-616.

[32] Bernardi, L., Porta, C., Casucci, G., Balsamo, R., Bernardi, R. and Bernardi, N.F., et al. (2009) Dynamic Interactions between Musical, Cardiovascular, and Cerebral Rhythms in Humans. Circulation, 119, 3171-3180.

[33] Trappe, H.J. (2010) The Effects of Music on the Cardiovascular System and Cardiovascular Health. Heart, 96, 1868-1871. https://doi.org/10.1136/hrt.2010.209858

[34] Naska, A., Oikonomou, E., Trichopoulou, A., Psaltopoulou, T. and Trichopoulos, D. (2007) Siesta in Healthy Adults and Coronary Mortality in the General Population. Archives of Internal Medicine, 167, 296-301. https://doi.org/10.1001/archinte.167.3.296

[35] Hoffmann, D. (1986) O Controle Natural do Stress. Ground, São Paulo.

[36] Pires do Rio, R. (1996) O Fascínio do Stress: Vencendo desafios num mundo em transformação. Qualitymark/Dunya, Rio de Janeiro. 
[37] Burg, M.M. (2007) Stress, Behavior \& Heart Disease. 2002. Scientific Eletronic. Library Online-Windows Internet Explorer. www.SciELO.org

[38] Paiva, S.A. (2002) Mito: Salvar Sempre? Os Limites do Humano. Revista de CardiologiaÓrgão de Divulgação Científica da Sociedade Brasileira de Cardiologia/MG, Sociedade Mineira de Cardiologia. Suplemento Especial Aspectos Psicológicos e Cardiologia, 8.

[39] Cateterismo Cardíaco, Portal São Francisco (2011). http://www.portalsaofrancisco.com.br/alfa/cateterismo-e-angioplastia/cateterismo-cardiaco s-7.php

[40] Galway, J. (1987) A Música no Tempo. Redigido por William Mann. Martins Fontes, São Paulo.

[41] Turato, E.R. (2008) Tratado da Metodologia da Pesquisa Clínico-Qualitativa: Construção teórico-epistemológica, discussão comparada e aplicação nas áreas da saúde e humanas. Vozes, Petrópolis.

[42] Bardin, L. (1977) Análise de Conteúdo. Edições 70, Lisboa.

[43] Jung, C.G. (1984) A Dinâmica do Inconsciente. Vozes, Petrópolis.

[44] Platel, H., Baron, J.C., Desgranges, B., Bernard, F. and Eustache, F. (2003) Semantic and Episodic Memory of Music are Subserved by Distinct Neural Networks. Neuroimage, 20, 244-256. https://doi.org/10.1016/S1053-8119(03)00287-8

[45] Platel, H. (2005) Functional Neuroimaging of Semantic and Episodic Musical Memory. Annals of the New York Academy of Sciences, 1060, 136-147. https://doi.org/10.1196/annals.1360.010

[46] Baumgartner, T., Lutz, K., Schmidt, C.F. and Jäncke, L. (2006) The Emotional Power of Music: How Music Enhances the Feeling of Affective Pictures. Brain Research, 1075, 151164. https://doi.org/10.1016/j.brainres.2005.12.065

[47] Blood, A.J. and Zatorre, R.J. (2001) Intensely Pleasurable Responses to Music Correlate with Activity in Brain Regions Implicated in Reward and Emotion. Proceedings of the National Academy of Sciences, 98, 11818-11823. https://doi.org/10.1073/pnas.191355898

[48] Baumgartner, T., Esslen, M. and Jäncke, L. (2006) From Emotion Perception to Emotion Experience: Emotions Evoked by Pictures and Classical Music. International Journal of Psychophysiology, 60, 34-43. https://doi.org/10.1016/j.ijpsycho.2005.04.007

[49] Baumgartner, T., Willi, M. and Jäncke, L. (2007) Modulation of Corticospinal Activity by Strong Emotions Evoked by Pictures and Classical Music: A Transcranial Magnetic Stimulation Study. Neuroreport, 18, 261-265. https://doi.org/10.1097/WNR.0b013e328012272e

[50] Buchanan, T.W. (2007) Retrieval of Emotional Memories. Psychological Bulletin, 133, 761779. https://doi.org/10.1037/0033-2909.133.5.761

[51] Eschrich, S., Münte, T.F. and Altenmüller, E.O. (2008) Unforgettable Film Music: The Role of Emotion in Episodic Long-Term Memory for Music. BMC Neuroscience, 9, 48. https://doi.org/10.1186/1471-2202-9-48

[52] Jäncke, L. (2008) Music, Memory and Emotion. Journal of Biology, 7, 21. https://doi.org/10.1186/jbiol82

[53] Craver, C.F. and Darden, L. (2001) Discovering Mechanisms in Neurobiology: The Case of Spatial Memory. In: Machamer, P., Grush, R. and McLaughlin, P., Eds., Theory and Method in Neuroscience, Pittsburgh University Press, Pittsburgh, 112-137.

[54] Dokic, J. (2001) Is Memory Purely Preservative? In: Hoerl, C. and McCormack, T. Eds., Time and Memory, Oxford University Press, Oxford, 213-232.

[55] Hoerl, C. (2007) Episodic Memory, Autobiographical Memory, Narrative: On Three Key Notions in Current Approaches to Memory Development. Philosophical Psychology, 20, 621-640. https://doi.org/10.1080/09515080701537988 
[56] Rubin, D.C. (2006) The Basic-Systems Model of Episodic Memory. Perspectives on Psychological Science, 1, 277-311. https://doi.org/10.1111/j.1745-6916.2006.00017.x

[57] Tulving, E. (1983) Elements of Episodic Memory. Oxford University Press, Oxford.

[58] Tulving, E. (2002) Episodic Memory: From Mind to Brain. Annual Review of Psychology, 53, 1-25. https://doi.org/10.1146/annurev.psych.53.100901.135114

[59] Tulving, E. (2005) Episodic Memory and Autonoesis: Uniquely Human? In: Terrace, H.S. and Metcalfe, J., Eds., The Missing Link in Cognition: Self-Knowing Consciousness in Man and Animals, Oxford University Press, Oxford, 3-56.

[60] Halpern, A.R. and Müllensiefen, D. (2007) Effects of Timbre and Tempo Change on Memory for Music. The Quarterly Journal of Experimental Psychology, 61, 1371-1384. https://doi.org/10.1080/17470210701508038

[61] Levitin, D.J. (1994) Absolute Memory for Musical Pitch: Evidence from the Production of Learned Melodies. Perception \& Psychophysics, 56, 414-423. https://doi.org/10.3758/BF03206733

[62] Peynircioglu, Z.F., Tekcan, A.I., Wagner, J.L., Baxter, T.L. and Shaffer, S.D. (1998) Name or Hum That Tune: Feeling of Knowing for Music. Memory \& Cognition, 26, 1131-1137. https://doi.org/10.3758/BF03201190

[63] Kohlmetz, C., Müller, S.V., Nager, W., Münte, T.F. and Altenmüller, E. (2003) Selective Loss of Timbre Perception for Keyboard and Percussion Instruments Following a Right Temporal Lesion. Neurocase, 9, 86-93. https://doi.org/10.1076/neur.9.1.86.14372

[64] Peretz, I. and Coltheart, M. (2003) Modularity of Music Processing. Nature Neuroscience, 6, 688-691. https://doi.org/10.1038/nn1083

[65] Zatorre, R.J., Belin, P. and Penhune, V.B. (2002) Structure and Function of Auditory Cortex: Music and Speech. Trends Cognitive Sciences, 6, 37-46.

https://doi.org/10.1016/S1364-6613(00)01816-7

[66] Cirlot, J.-E. (1984) Dicionário dos Símbolos. Editora Moraes, São Paulo, 84.

[67] Jung, C.G. (1875-1961) Os Arquétipos e o Inconsciente Coletivo. Petrópolis, Editora, Vozes, Petrópolis, Vol. 9/1, 87, OC.

\section{Submit or recommend next manuscript to SCIRP and we will provide best service} for you:

Accepting pre-submission inquiries through Email, Facebook, LinkedIn, Twitter, etc. A wide selection of journals (inclusive of 9 subjects, more than 200 journals)

Providing 24-hour high-quality service

User-friendly online submission system

Fair and swift peer-review system

Efficient typesetting and proofreading procedure

Display of the result of downloads and visits, as well as the number of cited articles

Maximum dissemination of your research work

Submit your manuscript at: http://papersubmission.scirp.org/

Or contact ojmp@scirp.org 